ГORIGINAL ARTICLE-

Volume 11 Issue 32019

DOI: 10.21315/eimj2019.11.3.3

ARTICLE INFO

Submitted: 25-04-2019

Accepted: 28-05-2019

Online: 31-10-2019

\section{Technology Enabled Formative Assessment in Medical Education: A Pilot Study through Kahoot}

\author{
Punithalingam Youhasan', Sanooz Raheem² \\ ${ }^{1}$ Department of Medical Education $\mathcal{E}$ Research, Faculty of Health- \\ Care Sciences, Eastern University, SRI LANKA \\ ${ }^{2}$ Department of Clinical Sciences, Faculty of Health-Care Sciences, \\ Eastern University, SRI LANKA
}

To cite this article: Youhasan P, Raheem S. Technology enabled formative assessment in medical education: a pilot study through Kahoot. Education in Medicine Journal. 2019;11(3):23-29. https://doi.org/10.21315/eimj2019.11.3.3

To link to this article: https://doi.org/10.21315/eimj2019.11.3.3

\begin{abstract}
Technology enabled assessment is a novel pedagogical approach that has emerged into medical educational practice. The main aim of formative assessment is to drive learning through constructive feedback. Kahoot is a free, real-time, game based, Web 2.0 learning platform, which is widely accepted to conduct formative assessment. The study aimed to explore the students' perception on using Kahoot as a formative assessment tool at Eastern University, Sri Lanka (EUSL). A total number of 61 medical students participated in this cross-sectional descriptive study following a formative assessment in pharmacology conducted via Kahoot at EUSL. The students' perceptions on Kahoot experience was evaluated by a self-administered questionnaire, which consisted 10 perception statements. The participants were asked to rate the statements using a 5-point Likert scale, ranging from 1 (strongly disagree) to 5 (strongly agree). Descriptive statistics were computed to present students' perception. This study revealed that most of the students $(83.6 \%)$ felt happy with Kahoot experience and $95.1 \%$ of them recommended Kahoot for formative assessment in future. Majority of the participants $(>90 \%)$ agreed or strongly agreed that Kahoot increases the focus on subjects, provides fun during learning, motivates to learn, and is an effective method for active learning and providing feedback. The general outcome shown in this study derived from the students gives Kahoot a place as a tool to enhance the learning and to provide feedback. The free availability, feasibility, the technical simplicity, and the enjoyable attitude from the students towards this application make this as a practical tool in Technology Enabled Assessment.
\end{abstract}

Keywords: Formative assessment, Technology-enhanced-assessment, Technology-enabled-assessment, Kahoot, Pharmacology

CORRESPONDING AUTHOR

Punithalingam Youhasan, Department of Medical Education \& Research, Faculty of Health-Care Sciences, Eastern University, No. 50, New Road, Batticaloa, Sri Lanka | E-mail: youhasanp@esn.ac.lk

\section{INTRODUCTION}

Technology is used as an integral tool for enhancing learning in Contemporary Medical Education (1). Technology enabled assessment is an emerging pedagogical approach, which offers a range of benefits over traditional paper-based assessment namely improve motivation, promote engagement, and enable effective feedback and learner-centeredness (2). In the digitalisation era, the younger generation is greatly exposed to gamification behaviour (3). Therefore, game-based learning 
and assessment has become popular in medical education (4). Kahoot is a free, real-time, game based, Web 2.0 learning platform, which is widely accepted for use in formative assessment (5). Between formative and summative assessments, formative assessment is mainly conducted to drive learning through providing feedback. Meanwhile, summative assessment is usually conducted at the completion of course/module, which displays the level of achievements of the learners (6).

Technology is used in several teaching activities and assessments in medical education. Recent improvement in programming, greater processing power of computers, more widespread availability of technology, and perhaps more importantly, an ongoing collaboration between educators and technologists are main contributing factors for the usage of technology in medical education (7). The technology has opened the access for examiners to work on the entire question cycle from various locations compared to the traditional methods of question settings (8).

The technology enhanced assessment can assess a broader domain when a simulation is used for assessment (9) and improves the learning by feedback (10). The feedback can be easily provided to a larger number of student groups compared to traditional assessments (11). The performances of the students who have participated in the online formative assessment has increased in their summative assessments (12).

The online assessment can be coordinated through programmes such as Kahoot and Learning Management System (LMS). Kahoot is used for providing metacognitive support, liveliness in class, and student attendance in higher education. Kahoot is a learning game conducted in the classroom with the student and it can be defined as the response system of the student. Multiple choice questions can be played with the students. The questions are formulated and displayed for the students, where the students will play by pressing the button for the correct answer from their phone/tablet/ laptop/computer. Points will be awarded for each correct answer and the motivation of the student is increased in a well-arranged classroom for the student to participate (13).

Kahoot is easy to join, and quizzes can be created with an interface designed in English. Teachers need to sign up on "getkahoot.com" to create an account while the students do not need an account to sign in. After creating the quiz or Kahoot games they can be used in classroom activities. Furthermore, the study questions equivalent to classroom lecture notes can be prepared by Kahoot. Each student can decide his/her own nickname when they play with Kahoot. The nicknames will appear on the screen while the students play, and it increases the liveliness of their participation and motivation. Kahoot can be logged in without downloading the application by the students. Videos and pictures can be included in the Kahoot assessments. The features in Kahoot can bring a real classroom like environment. But the limitation is the requirement of a stable internet or Wi-Fi connection (13).

Kahoot was introduced as a formative assessment tool in Pharmacology for undergraduate Medicine programme at Eastern University, Sri Lanka (EUSL). The objective of the study was to explore the students' perception on using Kahoot as a formative assessment tool at EUSL.

\section{METHODS}

This descriptive cross-sectional study was carried out at Faculty of Health-Care Sciences (FHCS), EUSL among 61 thirdyear medical students. The students were from different demographic categories representing both genders. This group of students had a formative assessment in pharmacology through Kahoot. The assessment included multiple choice questions. Each question was timed for two minutes. All the students participated in the assessment using their mobile phone. 
At the end of the assessment students were provided the questionnaire to express their experience in Kahoot. Ismail and Mohammad developed a tool to evaluate Kahoot experience among undergraduate medical students (4). The tool was used in the study to evaluate student perceptions on Kahoot experience. This tool consisted 10 perceptions statements and the participants were asked to rate the statements using a 5-point Likert scale, ranging from 1 (strongly disagree) to 5 (strongly agree).

All the questionnaires were coded and entered into an electronic database. Data analysis was carried out using SPSS version 22. Descriptive statistics was computed to present students' perception.

\section{RESULTS}

This study revealed that $83.6 \%$ of the participants felt happy with the Kahoot experience and more than $90.0 \%$ felt good about the Kahoot experience. Next, 95\% of the participants recommended Kahoot for future assessment activities (Figure 1).

Most of the participants (96.7\%) perceived that Kahoot practice and its' feedbacks enabled them to learn. Table 1 shows that all the 10 items received a mean score between 4 and 5 . These results indicated the students' positive perceptions towards the Kahoot experience. Interestingly, there was not any strong disagreement with Kahoot usage. Majority of the participants $(>90 \%)$ agreed or strongly agreed that Kahoot increases the focus on subjects, provides fun during learning, motivates to learn, and is an effective method for active learning and providing feedback.

The findings from students' perception can be categorised under the following areas: (a) with regard to factors associated to the learning; (b) factors associated to subject knowledge; and (c) factors associated to feedback.

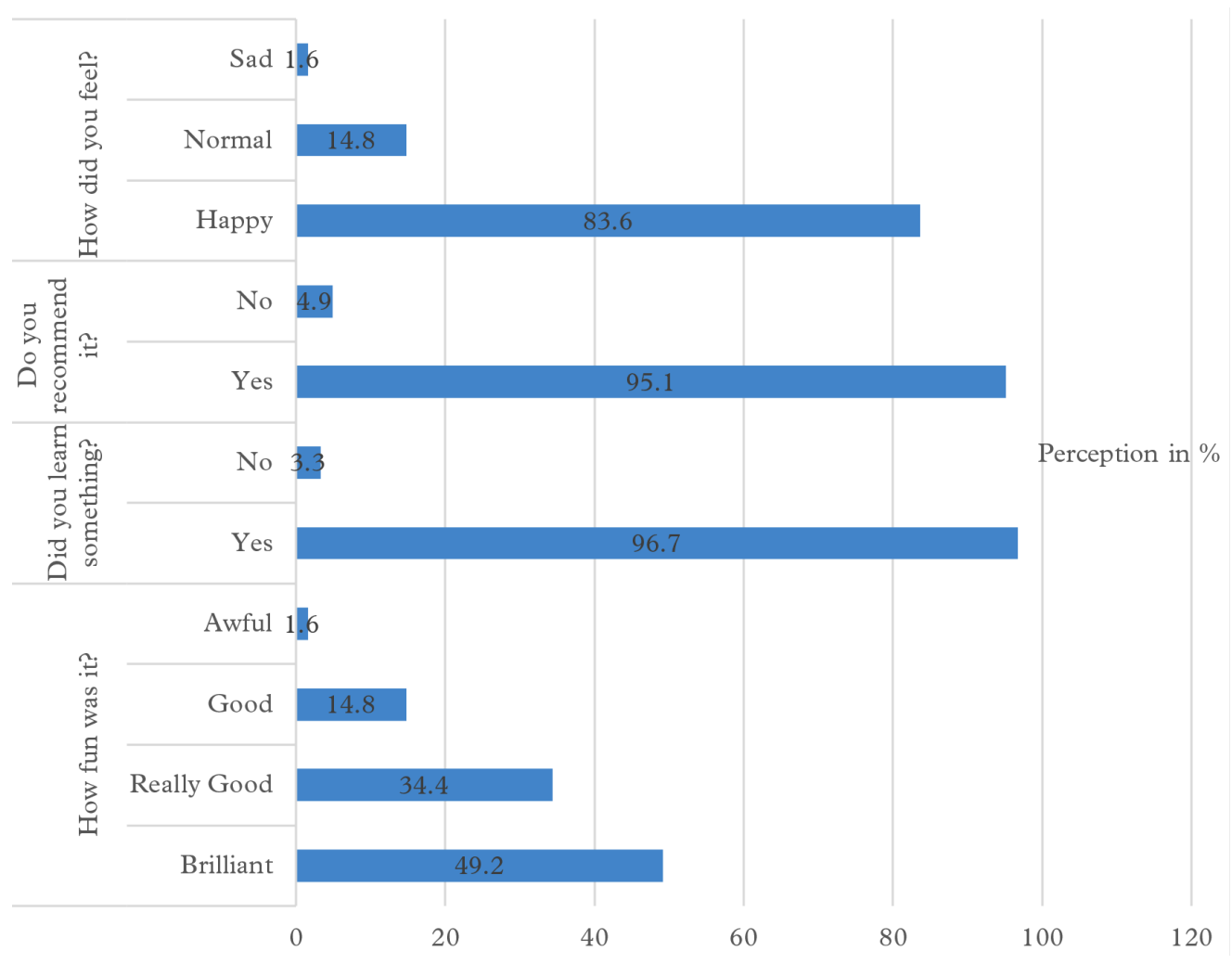

Figure 1: Students' feedbacks on Kahoot experience 
The questionnaire assessed the factors associated to the learning included the focus, motivation, fun, facilitation, and active learning. Majority of the students experienced a positive environment for learning (Table 1), whereby $98.4 \%$ of the students agreed that learning through Kahoot was fun and it motivated them to learn. Besides that, $95.1 \%$ of the students found Kahoot as a tool which increased the focus on the subject and as an effective tool for active learning.

The experience from the students regarding the subject knowledge included simplification of the subject, understanding of the subject, and retaining the subject knowledge. More than $80 \%$ of the students experienced that Kahoot was an effective tool to enhance all these three aspects associated to subject knowledge (Table 1).
While the factors associated to the feedback concerned around $80 \%$ of the students who had instant and live correction of their subject knowledge from the feedback they obtained through Kahoot, $95.1 \%$ of the students agreed that Kahoot was effective tool to provide feedback.

\section{DISCUSSION}

The results obtained in this study are similar to the findings obtained in the several other studies using Kahoot as a tool for formative assessment. It is proven that gamification can affect the motivation and behaviour of individual students. Furthermore, it encourages learning, problem solving skill, and renders education more enjoyable by encouraging social ties, learning processes, specialisation ability, ambition to achieve success in competitive environments,

Table 1: Students' perception about Kahoot experience

\begin{tabular}{|c|c|c|c|c|c|c|}
\hline \multirow[b]{2}{*}{ Statement } & \multicolumn{5}{|c|}{ Grading (\%) } & \multirow{2}{*}{$\begin{array}{l}\text { Mean score } \\
(\overline{\mathbf{x}})\end{array}$} \\
\hline & $\begin{array}{l}\text { Strongly } \\
\text { agree }\end{array}$ & Agree & Undecided & Disagree & $\begin{array}{l}\text { Strongly } \\
\text { disagree }\end{array}$ & \\
\hline $\begin{array}{l}\text { Kahoot helps me to focus on } \\
\text { the subjects }\end{array}$ & 45.9 & 49.2 & 4.9 & 0 & 0 & 4.40 \\
\hline $\begin{array}{l}\text { Kahoot motivates me to learn } \\
\text { more }\end{array}$ & 57.4 & 41.0 & 1.6 & 0 & 0 & 4.56 \\
\hline Learning with Kahoot is fun & 60.7 & 37.7 & 1.6 & 0 & 0 & 4.59 \\
\hline $\begin{array}{l}\text { Kahoot enhances my } \\
\text { understanding on the } \\
\text { subjects }\end{array}$ & 34.4 & 50.8 & 14.8 & 0 & 0 & 4.20 \\
\hline $\begin{array}{l}\text { Kahoot helps to retain my } \\
\text { knowledge }\end{array}$ & 41.0 & 44.3 & 11.5 & 3.3 & 0 & 4.23 \\
\hline $\begin{array}{l}\text { Kahoot simplifies the complex } \\
\text { subjects }\end{array}$ & 36.1 & 47.5 & 14.8 & 1.6 & 0 & 4.18 \\
\hline $\begin{array}{l}\text { Kahoot facilitates my learning } \\
\text { on the subjects }\end{array}$ & 47.5 & 37.7 & 13.1 & 1.6 & 0 & 4.31 \\
\hline $\begin{array}{l}\text { Kahoot is an effective method } \\
\text { to provide feedback }\end{array}$ & 42.6 & 52.5 & 3.3 & 1.6 & 0 & 4.36 \\
\hline $\begin{array}{l}\text { Kahoot is an effective method } \\
\text { to correct my misconception } \\
\text { on the subjects }\end{array}$ & 42.6 & 37.7 & 18.0 & 1.6 & 0 & 4.21 \\
\hline $\begin{array}{l}\text { Kahoot is an effective method } \\
\text { for active learning }\end{array}$ & 57.4 & 37.7 & 1.6 & 3.3 & 0 & 4.49 \\
\hline
\end{tabular}


competition, and enthusiasm of changing status, while motivating students to solve problems and partake in educational activities. Gamification makes the students learn difficult subjects easily and with fun (13).

The factors associated with enhancing the learning process have been reflected by this pilot study, where it is evident that Kahoot contributes to a strong positive learning environment for the students in the aspects of fun, focus, motivation, facilitation, and enhancing the active learning. This can be attributed to the gamification effect of the Kahoot tool and the current skills and attitude of the students. Moreover, the students in the current technological era find it convenient to learn a subject through Kahoot based on this study's findings, where they have found Kahoot as a tool which simplifies, enhances their understanding of the subject, and especially it helps to retain their subject knowledge. These are very positive perceptions from the students, which have reflected from them about having a better knowledge of a subject and retaining that knowledge. It is important in medical profession to retain knowledge and skill. This pilot study promises that Kahoot can contribute in this aspect.

It has been determined that Kahoot is designed attractively to be used by the students and the teachers without any inconveniences as well as it promotes an educational competitive environment among the students within the classroom. It is a fast-performing application and a very much user-friendly software. Kahoot can be used to review old lesson content and can be used to evaluate research projects and presentations. Kahoot has been enjoyed by the students as an element in flipped classrooms $(4,13)$.

Kahoot has been shown as an effective tool to provide real time feedback to students.
The frequent feedback to students will fill the gap between their knowledge and what they are expected to know (4). This is apparent from this present study that more than $95 \%$ of the students had their real time feedback and around $80 \%$ of the students were able to correct their misconceptions in the subject knowledge. The conventional system, compared to Kahoot, does not involve the student in real time and the feedback is provided by the teacher and perceived by the students. However, Kahoot actively involves the students themselves in the assessment and provide a room for them in the real time competitive mode, which make them play the questions with the whole classroom where they obtain the real time score for each question, which is a live feedback they get and it provides them a spark in their knowledge about the misconception and the level of knowledge they have about the subject. This phenomenon makes the students to effectively engulf the feedback and correction of their knowledge. This benefit is difficult to be filled by the conventional feedback system by the teachers.

The identified problems associated with using Kahoot are the need for a stable internet connection and Kahoot's inability to simplify complex problems. Even though Kahoot makes the difficult subjects enjoyable to the students by its design, it does not simplify the complexity of the subject $(4,13)$. This study had a different finding in the aspect of simplifying the complex subject. More than $80 \%$ of the students mentioned that Kahoot simplifies the complex subjects and this finding can be attributed to the individual subject topic assessed, the discipline of subject assessed in the formative assessment, and to the assessed population. To overcome this problem, more Kahoot formative assessments in other subject topics, disciplines, and on different population of medical students should be conducted. 


\section{CONCLUSION}

The undergraduate medical students of EUSL showed high likelihood of perception to formative assessment with gamification approach.

This pilot study has promising outcomes in the process of learning, subject knowledge, and feedback which can be achieved through Kahoot. The technological simplicity, free availability, students' recommendations, its features in providing real time feedback, and the availability of smart devices make Kahoot a much feasible tool in technology enhanced assessment.

Further studies are recommended with Kahoot among various populations in different subject disciplines and subject areas to make the use of Kahoot individualised in the process of medical education.

\section{ACKNOWLEDGEMENTS}

We would like to thank the Dean of FHCS, EUSL and the Head, Department of Medical Education and Research for their immense support by granting us the permission to carry out this study. We would like to convey our sincere gratitude to all the students who participated in the study. This research did not receive any specific financial grant.

\section{REFERENCES}

1. Ellaway R, Masters K. AMEE Guide 32: e-Learning in medical education Part 1: learning, teaching and assessment. Med Teach. 2008;30(5):455-73. https://doi. org/10.1080/01421590802108331

2. Erhel S, Jamet E. Digital game-based learning: impact of instructions and feedback on motivation and learning effectiveness. Comput Educ. 2013;67:156-67. https://doi. org/10.1016/j.compedu.2013.02.019
3. Sung $H$, Hwang G. A collaborative game-based learning approach to improving students' learning performance in science courses. Comput Educ. 2013;63:43-51. https://doi.org/10.1016/j. compedu.2012.11.019

4. Ismail M, Mohammad J. Kahoot: a promising tool for formative assessment in medical education. Education in Medicine Journal. 2017;9(2):19-26. https://doi. org/10.21315/eimj2017.9.2.2

5. Plump C, LaRosa J. Using Kahoot! in the classroom to create engagement and active learning: a game-based technology solution for eLearning novices. MTR. 2017;2(2):151-58. https://doi. org/10.1177/2379298116689783

6. Taras M. Assessment - summative and formative - some theoretical reflections. $\mathrm{Br} \mathrm{J}$ Educ Stud. 2005;53(4):466-78. https://doi. org/10.1111/j.1467-8527.2005.00307.x

7. Pellegrino JW, Quellmalz ES. Perspectives on the integration of technology and assessment. J Res Technol Educ. 2010;43(2):119-34. https://doi.org/10.1080/ 15391523.2010 .10782565

8. Questionmark. About us. [updated 2019; cited 2019 Apr 22]. Available from: https:// www.questionmark.com/content/about-us

9. Amin Z, Boulet JR, Cook DA, Ellaway R, Fahal A, Kneebone R, et al. Technologyenabled assessment of health professions education: consensus statement and recommendations from the Ottawa 2010 conference. Med Teach. 2011;33(5):36469 . https://doi.org/10.3109/014215 9X.2011.565832

10. Hattie J, Timperley H. The power of feedback. Rev Educ Res. 2007;77(1):81-112. https://doi. org/10.3102/003465430298487 
11. Edward P, Peter D: The assessment of a structured online formative assessment program: a randomised controlled trial. BMC Med Educ. 2014;14:8. https://doi. org/10.1186/1472-6920-14-8

12. Kibble J. Use of unsupervised online quizzes as formative assessment in a medical physiology course: effects of incentives on student participation and performance. Adv Physiol Educ. 2007;31(3):253-60. https://doi.org/10.1152/advan.00027.2007
13. Huseyin Bicen, Senay Kocakoyun: Perceptions of students for gamification approach: Kahoot as a case study. iJET. 2018;13(2):72-93. (2018). https://doi. org/10.3991/ijet.v13i02.7467 